\title{
Is There a Problem of Immunodeficiency in Long-Term Plateletpheresis Donors?
}

In the last few years, recommendations, guidelines, and laws have all served as important motivators, not just for improving the quality of medical products such as blood components but also for carefully and comprehensively guaranteeing the safety of blood donors. The German Guidelines for the Collection of Blood and Blood Components from 2000 [1] allow 26 thrombocytaphereses per year without the need for a threepart white blood cell (WBC) differentiation, whereas the apheresis frequency is limited to 24 procedures in the yet to be updated FDA guidelines from 1988 [2] which point out the magnitude of potential risks, especially lymphocyte depletion. Nowadays, this old-fashioned recommendation can only be understood by bearing in mind that the first generation of cell separators generated platelet concentrates with WBC contaminations in the order of $10^{9}$ cells per concentrate [3].

Over the last three decades, the question of immune deficiency arising from frequent blood donations has been raised repeatedly. The paper of Carrero et al. [4] published in this issue also deals with the theme of analyzing the cellular immune status amongst thrombocytapheresis donors. These results and many other published contributions provide clear and definitive evidence that a slight loss of leukocytes, especially lymphocytes, does not impair the donor's immune system in its struggle against bacteria, parasites, viruses, and cancer $[5,6]$. Table 1 summarizes the relative WBC loss with different blood donation techniques. The technical improvements of the newer generations of cell separators have resulted in very low WBC contaminations, i.e. $<1 \times 10^{6}$, or sometimes even $<1 \times 10^{5}$ cells per platelet concentrate [7-13] (overview table 2 ). These efforts have been made to avoid or reduce the risks of alloimmunization against human leukocyte antigens (HLA), the appearance of nonhemolytic transfusion reactions (NHFTR) due to cytokine accumulation, and the transmission of intracellular pathogens. Besides this, the introduction of leukocyte-poor platelet concentrates assists in preventing the donor's immune system from falling into disequilibrium over the short and long term following frequent apheresis [6].
In humans, lymphoid and myeloid progenitor cells develop from the pluripotent stem and progenitor cell pool of the bone marrow. While immature T lymphocytes mature in the thymus and are subjected to a negative and positive selection process involving various mechanisms (e.g. induction of programmed cell death in autoreactive clones), B cells mature in a bone marrow microenvironment in close contact with hematopoietic and stromal elements. Differentiated mature lymphatic cells migrate to the peripheral lymphatic organs (spleen, lymph glands). During this process, both B and T lymphocytes circulate and recirculate in peripheral blood. Therefore, the cellular immune status obtained from multi-parameter flow-cytometric analysis of peripheral blood samples does not totally reflect the complexity of the human immune system and its different compartments. This knowledge has to be taken into account when quantitative measurements of lymphocyte subsets are considered for drawing conclusions on the intactness or impairment of the immune system. In addition, the immune system is in a kinetic steady state, i.e. there is a balanced cell traffic between the blood and the lymphatic organs, and vice versa, whereby the cell proliferation and cell death rates are equal [14]. The sizes of the T- and B-cell pools are maintained independently from each other and are relatively constant within individuals. However, interindividual variability is higher to the extent that normal ranges for lymphocyte subsets are wide; for example, concentrations of CD3+ T lymphocytes

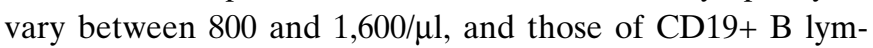
phocytes between 200 and $400 / \mu 1$ in peripheral blood. A description of the quantitative distribution of these lymphocytes is of limited value for describing immunocompetence and correlating the results obtained with the clinical status of the patients.

Analysis of lymphocyte turnovers allows insights to be made into the regulation pathways of a finely tuned cellular immune system under homeostatic control at rest and into the degree of activation which can be induced dynamically upon stimulation. The estimation of lymphocyte lifespans, mainly analyzed

\begin{tabular}{ll}
\hline KARGER & @ 2000 S. Karger GmbH, Freiburg \\
Fax +497614520714 & Accessible online at: \\
$\begin{array}{l}\text { E-mail Information@Karger.de } \\
\text { www.karger.com }\end{array}$ & www.karger.com/journals/iut
\end{tabular}

Dr. med. Peter Schlenke

Institut für Immunologie und Tranfusionsmedizin

Medizinische Universität Lübeck

Ratzeburger Allee 160, D- 23538 Lübeck (Germany) 
in animal models, is based on the incorporation of labelled DNA analogues ([ $\left.{ }^{3} \mathrm{H}\right]$ thymidine or 5-bromo-2'-desoxyuridine), cytostatic drug assays, or, more recently, detection of mature donor lymphocytes in recipients' organs using allogeneic transplant models [14]. There is growing evidence that

Table 1. Absolute WBC loss depending on the sampling/donation technique

\begin{tabular}{lll}
\hline & $\begin{array}{l}\text { White blood cells } \\
\text { (total) }\end{array}$ & $\begin{array}{l}\text { Lymphocytes } \\
\text { (total) }\end{array}$ \\
\hline Blood sample $(10 \mathrm{ml})$ & $5-10 \times 10^{7}$ & $1.2-2.5 \times 10^{7}$ \\
Whole-blood donation $(500 \mathrm{ml})$ & $2.5-5 \times 10^{9}$ & $0.6-1.2 \times 10^{9}$ \\
Plateletpheresis* & $<1 \times 10^{6}$ & $<0.25 \times 10^{6}$ \\
\hline
\end{tabular}

*Newer generation. lymphocytes have high proliferation and turnover rates while they mature in the bone marrow and thymus. In contrast, the conditions influencing the lifespan of circulating lymphocytes and their subsets (virgin/memory) are not completely understood. While migrating in secondary lymphoid tissues, their disappearance in the peripheral blood and their ability to recirculate repeatedly make it more difficult to determine turnover rates. Current opinion dictates that about $30 \%$ of peripheral immunocompetent B and T cells are renewed every 3 days and that mature lymphocytes contain both short-term and long-term subsets [14]. The dynamic process of lymphocyte proliferation and expansion following antigenic challenge reinforces the idea that WBC loss during frequent plateletpheresis does not influence the homeostasis of the cellular immune system.

In conclusion, frequent plateletpheresis does not lead to a significant and clinically relevant loss of WBCs such as immuno-

Table 2. WBC contamination with different plateletpheresis techniques (literature selection)

\begin{tabular}{|c|c|c|c|c|c|}
\hline \multirow[t]{2}{*}{ Authors } & \multirow[t]{2}{*}{ Separator } & \multirow[t]{2}{*}{ Supplements } & \multirow[t]{2}{*}{ WBC contamination } & \multicolumn{2}{|c|}{ WBC apheresis, \%: } \\
\hline & & & & $<1 \times 10^{6}$ & $<5 \times 10^{6}$ \\
\hline \multirow[t]{2}{*}{ Zeiler et al., 2000 [13] } & \multirow[t]{2}{*}{ AS.TEC 204} & PAIP & $3.0 \times 10^{4}$ & 92 & 98 \\
\hline & & FIP & $2.3 \times 10^{6}$ & 32 & 71 \\
\hline \multirow{2}{*}{ Perseghin et al., 2000 [12] } & \multirow{2}{*}{ COBE Spectra } & LRS 5.1 & $6.0 \times 10^{4}$ & 99 & 99 \\
\hline & & LRS 7.0 & $0.2 \times 10^{6}$ & 97 & 99 \\
\hline \multirow[t]{2}{*}{ Triulzi et al., 2000 [6] } & COBE Spectra & LRS V5 & $2.0 \times 10^{4}$ & 100 & - \\
\hline & AMICUS & Version 2.37 & $<1.0 \times 10^{4}$ & 100 & - \\
\hline \multirow[t]{2}{*}{ Moog et al., 1999 [11] } & AS.TEC 204 & PAIP & $0.9 \times 10^{6}$ & $74 *$ & 100 \\
\hline & AMICUS & - & $0.3 \times 10^{6}$ & $92 *$ & 100 \\
\hline \multirow[t]{2}{*}{ Benjamin et al., 1999 [10] } & COBE Spectra & LRS software V5 & - & 100 & - \\
\hline & AMICUS & Version 2.37 & - & 100 & - \\
\hline \multirow{2}{*}{ Yockey et al., 1998 [8] } & AMICUS & Version $2.12-2.34$ & - & $99 / 100$ & $100 / 100$ \\
\hline & COBE Spectra & LRS software V5 & - & 100 & 100 \\
\hline Zingsem et al., 1998 [9] & COBE Spectra & LRS software & $1.0 \times 10^{4}$ & 100 & - \\
\hline \multirow[t]{2}{*}{ Moog et al., 1998 [7] } & AS.TEC 204 & Version 4.7 & $2.1 \times 10^{4}$ & - & 87.5 \\
\hline & AMICUS & Version 2.34-2.37 & $0.2-0.4 \times 10^{6}$ & - & 100 \\
\hline \multirow[t]{3}{*}{ Strauss et al., 1994 [5] } & COBE Spectra & - & $8.5 \times 10^{6}$ & - & 77 \\
\hline & CS3000 & TNX-6 plus & $5.9 \times 10^{7}$ & - & 31 \\
\hline & Haemonetics & $\mathrm{MCS}+$ & $3.0 \times 10^{7}$ & - & 20 \\
\hline \multirow[t]{2}{*}{ Burgstaler et al., 1993 [15] } & COBE Spectra & P 2.5/3.6 & $0.6-1.3 \times 10^{6}$ & - & $100 / 85$ \\
\hline & CS3000 & TNX-6 plus(IO-6/8) & $0.2-5.3 \times 10^{6}$ & - & $100 / 45$ \\
\hline \multirow[t]{3}{*}{ Kretschmer, 1991 [16] } & Cobe Spectra & - & $0.5 \times 10^{7}$ & - & - \\
\hline & AS-104 & P-No.18/V 4.11 & $1.1 \times 10^{7}$ & - & - \\
\hline & CS3000 & TNX-6/Standard & $3.9-9.0 \times 10^{7}$ & - & - \\
\hline \multirow[t]{3}{*}{ Strauss et al., 1984 [3] } & Haemonetics & Model 30 & $3.0-5.0 \times 10^{9}$ & - & - \\
\hline & IBM & 2997 & $5.0-10.0 \times 10^{9}$ & - & - \\
\hline & CS3000 & Standard & $3.0-5.0 \times 10^{8}$ & - & - \\
\hline
\end{tabular}

*Estimated.

LRS = Leukocyte reduction system; PAIP = periodically alternating interface position; FIP = Fixed interface position. 
competent $\mathrm{B}$ and $\mathrm{T}$ cells, since i) a total of $10^{10}$ of these cells circulate in the peripheral blood for immune surveillance, ii) they have high daily turnover rates, and iii) their specific regulated recruitment mechanisms from cellular pools and their expansion conditioned by hormones, growth factors and cellcell contact all proceed in good time, as does the clonal ampli- fication of antigen-specific cytotoxic $\mathrm{T}$ lymphocytes. There are no convincing results which reinforce the hypothesis that a slight depression of specific immune cells or the selective depletion of any known lymphocyte subset in the peripheral blood compartment contributes to a physiologically significant immune deficiency.

P. Schlenke, H. Kirchner (Lübeck)

\section{References}

1 Richtlinien zur Gewinnung von Blut und Blutbestandteilen und zur Anwendung von Blutprodukten (Hämotherapie). Aufgestellt vom Wissenschaftlichen Beirat der Bundesärztekammer und vom Paul-Ehrlich-Institut. Bundesgesundheitsblatt 2000;43:555-589.

2 Division of Blood and Blood Products, Center for Biologics Evaluation and Research: Bethesda, MD: Food and Drug Administration: Guideline for the collection of platelets, pheresis prepared by automated methods. October 1988

3 Strauss RG: Apheresis donor safety - changes in humoral and cellular immunity. J Clin Apheresis 1984;2:68-80.

4 Carrero I, Kroeger N, Schaefer P, Kuehnl P, Gutensohn K: A two-year flow cytometric immune surveillance of plateletapheresis donors. Infus Ther Transfus Med 2000;27:302-306.
5 Strauss RG: Effects on donors of repeated leukocyte losses during plateletpheresis. J Clin Apheresis 1994;9:130-134.

6 Triulzi DJ, Meyer EM, Donnenberg AD: WBC subset analysis of WBC-reduced platelet components. Transfusion 2000;40:771-780.

7 Moog R, Müller N, Goergens D: Platelet collection with the Amicus and the AS.TEC 204 blood cell separators. Transfusion 1998:38:285-289.

8 Yockey C, Murphy S, Eggers L, Garratty G, Dingle A, Helms C, Moroff G: Evaluation of the Amicus separator in the collection of apheresis platelets. Transfusion 1998;38:848-854.

9 Zingsem J, Glaser A, Weisbach V, Zimmermann R, Neidhardt B, van Waeg G, Eckstein R: Evaluation of a platelet apheresis technique for the preparation of leukocyte-reduced platelet concentrates. Vox Sang 1998;74:189-192.

10 Benjamin RJ, Rojas P, Christmas S, Neal J, Broughton S, Burgio C, Barrett B, Churchill WH: Plateletpheresis efficiency: A comparison of Spectra LRS and AMICUS separators. Transfusion 1999;39:895-899.
$11 \operatorname{Moog}$ R, Müller N: White cell reduction during plateletpheresis: A comparison of three blood cell separators. Transfusion 1999;39:572-577.

12 Perseghin P, Mascaretti L, Riva M, Sciorelli G: Comparison of plateletpheresis concentrates produced with Spectra LRS version 5.1 and LRS Turbo version 7.0 cell separators. Transfusion 2000; 40:789-793.

13 Zeiler T, Zingsem J, Moog R, Kretschmer V, Eckstein R, Müller N, Eisenbeisz F: Periodic alternating interface positioning to lower WBC contamination of apheresis platelet concentrates: A multicenter evaluation. Transfusion 2000;40:687-692.

14 Freitas AA, Rocha BB: Lymphocyte lifespans: Homeostasis, selection and competition. Immunol Today 1993;14:25-29.

15 Burgstaler EA, Pineda A, Brecher MA: Plateletpheresis: Comparison of platelet yields, processing time, and white cell content with two apheresis systems. Transfusion 1993;33:393-398.

16 Kretschmer V: Comparison of different plateletpheresis systems. Infusionstherapie 1991;18:188190. 